\title{
The Influence of R\&D on Economic Development in the West African Sub-Region
}

\author{
Ayamba Emmanuel Caesar'1, Haibo Chen'1, Thomas Bilaliib Udimal'2, Andrew Osei-Agyemang1 \\ ${ }^{1}$ School of Finance and Economics, Jiangsu University, Zhenjiang, China \\ ${ }^{2}$ School of Management and Engineering Science, Jiangsu University, Zhenjiang, China \\ Email: eaayamba@bpoly.edu.gh
}

How to cite this paper: Caesar, A.E., Chen, H.B., Udimal, T.B. and Osei-Agyemang, A. (2018) The Influence of R\&D on Economic Development in the West African Sub-Region. Open Journal of Social Sciences, 6, 215-228. https://doi.org/10.4236/jss.2018.63015

Received: February 9, 2018

Accepted: March 26, 2018

Published: March 29, 2018

Copyright (c) 2018 by authors and Scientific Research Publishing Inc. This work is licensed under the Creative Commons Attribution International License (CC BY 4.0).

http://creativecommons.org/licenses/by/4.0/

\section{(c) (i) Open Access}

\begin{abstract}
The purpose of this paper was to study the influence of $R \& D$ (which included capital, labour and human capital) on economic development in the West African sub-region. However, due to unavailability of data to cover these variables, proxies were used to represent the independent variables. The proxies used were gross fixed capital formation, GDP per person employed, government expenditure on tertiary education as a percentage of GDP and gross enrolment ratio of both sexes to represent capital, labour, R\&D and human capital respectively. The study covered all the 15 member-states of the Economic Commission of West African States (ECOWAS). The study covered a period of 2001-2014. The Generalised Least Squares (GLS) method of estimation was adopted with a panel dataset. The findings revealed that the variables had positive impact on the economy while R\&D did influence GDP per capital significantly though weakly positive.
\end{abstract}

\section{Keywords}

Research \& Development Expenditure, Economic Growth, Panel Data Analysis

\section{Introduction}

The African continent is by far the second-largest and second-most-populous continent in the world, endowed with rich natural resources and yet the poorest, [1]. For the first time in world history, due to the sustained economic growth which China and India have experienced over the past 20 years, the majority of the world's poor (living on $\$ 1$ a day or less) countries are in Africa [2].

The economic situation in West Africa remains fragile and vulnerable to domestic and external shocks [3]. Investment remains subdued, limiting efforts to 
diversify economic structures and boost growth [4]. Furthermore, the last decade has seen a dramatic change in the character of violence in West Africa. Violence has shifted away from the large-scale conflict events and intrastate wars that characterized the postcolonial and post-cold war periods toward an increase in low-level insurgencies and political violence by non-state actors [5]. These conflicts and other adverse factors, notably poor weather conditions and deterioration in the terms of trade, have led to loss in economic momentum in the region over the last two decades [1] [3] [4].

Hiking poverty rates, market assimilation difficulty into world markets, stagnant economic growth rates, higher unemployment etc. are some challenges the West African sub-region faces. In addition, the following are some destabilising factors posing threats to the sub-region: the fragility of states in the region, internal power struggles, growing militarisation, rapid population growth, a general climate of insecurity which fuels trafficking of all kinds, and lastly various foreign interventions aimed at gaining a toe-hold in this strategic corridor and taking control of its wealth [6]. There is no doubt that the results of these conflicts and other destabilising factors are devastating economies in the sub-region. This according to Ghura, Basu and Calamitsis [1] can be mitigated if conscious efforts are made by the political leaders to ensure significant rise in the real GDP per capita growth rates, enhancement in social conditions and stability in the political arena.

Despite the above findings from Ghura, Basu and Calamitsis [1], Sylwester [7] calls for a tremendous rise in the time and amounts invested in research and development $(\mathrm{R} \& \mathrm{D})$ towards economic growth by governments. Over the past two centuries, some attributions have been made to improvements in economic growth and living standards to innovation. This is however suggested by some proponents that a well-motivated and sustained R\&D sector will lead to a technologically advanced environment. This could lead to higher productivity and benefits from economics of scale, thereby ensuring that there are employment opportunities and the workers earn high wage rates and improved standard of living. The importance of $\mathrm{R} \& \mathrm{D}$ to economic growth has been well recognised to involve coming up with well-designed and efficient production techniques in the current production process and the creation of new and improved products.

Could these accessions raise questions ranging from the accuracy of these views? Do countries with huge R\&D expenditure enjoy faster economic growth rate? And do those countries with more R\&D expenditure enjoy from higher productivity? These are questions worth finding answers. Consequently, it is incumbent on governments to support the growth and development of R\&D through funding or any other means possible particularly if it is lacking in the private business environment.

Irrespective of the importance of $\mathrm{R} \& \mathrm{D}$ to economic growth that is theoretically having a positive effect on economic growth, empirically there are some challenges in its measurement. These measurement challenges may include differences in aggregated level (companies, industries or countries), sources of data 
(time periods, countries) and measurements of key variables (stocks, flows or differences) [8].

The aim of this paper was to investigate the role of research and development expenditures on economic growth of all member states of Economic Community of West African State (ECOWAS). The pushing factor for this paper is that literature [9] shows that economies of developed countries experience advancement in their economies because of the reliance on R\&D. On the contrary, economies of ECOWAS countries are either undeveloped or developing. This paper therefore intended to find out whether it is because the ECOWAS countries have failed to comply to the directive from the African Union (AU) to allocate about $1 \%$ from their respective GDP towards the enhancement of R\&D.

To the best of our knowledge, there has been little or no information regarding the impact of $\mathrm{R} \& \mathrm{D}$ on economic growth for ECOWAS member states ${ }^{1}$. This derives our passion for writing this paper. The paper is organized as follows: Section 1 presents the introduction; Section 2 reviews of the literature; Section 3 is an overview of Gross Domestic Product (GDP) and R\&D in West African (WA) countries; Section 4 is an augmented Solow model that incorporates R\&D and human capital; Section 5 is the methodology and the econometric results; while Section 6 outlines the main conclusions and policy implications of our research.

\section{Review of Literature}

The engine of economic growth depends on the pace of technological advancement and level of innovation among entrepreneurs in a country. Entrepreneurs have a major role in the development agenda of a country. That is their performances should be based on innovative ways which could generate well designed and efficient production techniques in the current production process and the creation of new and improved products for existing and emerging markets [10]. Therefore, technological advancement influences economic growth greatly. According to Romer [11], in his Endogenous Growth Model (EGM), he establishes a link between investment in R\&D sector ${ }^{2}$ and rate of economic growth through the skilful innovations of research workers whom might have accumulated knowledge over the past years of doing research. This may imply that R\&D maybe a necessary but not sufficient condition for economic development. A skilful and active labour force (human capital) maybe needed to augment the investments to develop the R\&D sector.

Most governments over the past years have acknowledged the significance of $\mathrm{R} \& \mathrm{D}$ to economic growth. They therefore have invested more large amounts of money on regular basis to the development of research institutions. However, ${ }^{1}$ Benin, Burkina Faso, Cape Verde, Cote d'Ivoire, The Gambia, Ghana, Guinea, Guinea-Bissau, Liberia, Mali, Niger, Nigeria, Senegal, Sierra Leon and Togo.

${ }^{2} \mathrm{R} \& \mathrm{D}$ can lead to the development of new products, improve upon the performance and quality of existing products and also to adapt effective and efficient ways to enhance the current production process. 
some scholars are calling for yet more increased investments in this sector. This has led to most governments facing various competing demands for public funding, especially on how much allocation to education, health, research and other sectors is required. In line with this, in the endogenous growth literature of Romer [11], Ghura, Basu and Calamitsis [1], Sylwester [7], and Ulku [12] emphasis are made for governments to be actively involved in the development of a vibrant $R \& D$ sector by investing in the development of human capital (education). They assumed countries with exceedingly increase in growth rate of education will have a speedy evolutionary growth rates in their wages and the economy as a whole, thus, seeing human capital as an added input to enhance economic development. In addition, Pissarides [13] argues that the effect of education on growth will be based on the eminence of education coupled with how labour markets are able to competently distribute work force in the production process. It is more often than not the case that once an innovation is relatively successful other industry players tend to imitate it [14]. The consequences of R\&D breed creativity and generation of new ideas. Therefore, the fusion of these new ideas and creativity with successful innovative practices from other industry players produces new value. The impact will yield economic growth and development in a national economy and to the global economy in general [15].

In regards to this, Salter and Martin [16] critically review the economic benefits accruing from publicly funded basic research. They identify surveys, econometric studies and case studies as the main methods used in establishing a relationship between R\&D expenditure and economic performance. Although econometric studies are plagued by methodological limitations, they revealed substantial economic benefits and the existence of localisation and spill over effects. From their review on case studies and surveys, the benefits of public investment in basic research fall under these categories: increasing the capacity for technological and scientific problem-solving, creating new scientific methodologies and instrumentation, creation of new firms, stimulating social interaction and forming networks, increasing the stock of useful knowledge and training skilled graduates. These benefits vary in their importance depending on the nature of the technology, scientific field and the industrial sector. While considering the notion for government funding of basic research, they argue that to take into consideration of these varying benefits of basic research, the extension of the traditional 'market failure' justification is needful.

Varying researches have revealed several findings with regards to the influence of $\mathrm{R} \& \mathrm{D}$ on economic growth using panel data analysis. These researches vary from different panels, time periods, variables and econometric methods. A study was conducted by Gumus and Celikay [17], comparing the economic growth rate between developed and developing countries per GDP expenditure on $R \& D$, their findings were that in the long run the investment on $R \& D$ will be significantly and positively influencing the growth of the economy for all the 
countries under study. However, in the short run there will be a feeble influence on the economies of developing countries but will be stronger in the long run. Furthermore, Dulleck and Foster [18] concluded in their cross-country research that higher productivity is inevitable in countries with different levels of human capital if R\&D spill overs are facilitated by higher investment in equipment and innovation. Their research revealed that for countries with human capital been low there is a weak influence among technology and innovation (as proxy to human capital) and growth of the economy, whereas for countries with human capital been high there is a relatively higher influence among technology and innovation (as proxy to human capital) and growth of the economy.

Sadraoui et al. (2014) analysed the causality between R\&D collaboration and economic growth by using the data of 32 industrialized and developed country for the period between 1970-2012. Results obtained support the argument that there is a strong causality between economic growth and $\mathrm{R} \& \mathrm{D}$ collaboration. On the contrary, the non-causality between $\mathrm{R} \& \mathrm{D}$ collaboration and economic growth couldn't be refused in several contexts. However, these results show that, if there is such a relationship, a Granger causality test with one or two variants can't be defined easily.

From the African experience, Alani [19] concluded their study of the Ugandan economy that a boom in economic growth could be influenced by an increase in the intensity of technology; capital stock and labour. This implied that the relationship that fostered between the growth rate, output level and technology is a constant and decreasing return to scale. Using the augmented Solow human-capital growth model, Anaduaka [20] investigated the impact or effect of human capital development on the Nigeria economy. There were two cointegrating equations or vectors among the variables of interest which were identified using the Johansen 2 likelihood ratio test statistics, the trace and maximal eigenvalue cointegration test statistics. Indications from regression estimates revealed the relationship between Nigeria's economic growth and public investment on education, human capital and total capital formation is positive and therefore statistically significant. Irrespective of the world economic crisis coupled with South Africa's long history apartheid and economy fragility, efforts are made to ensure the country's development are on the right path. According to Nicolaides [15] the government of South Africa is critical in building a knowledge-based economy. This they (government) do by increasing the public investment on R\&D in the 23 Universities in South Africa as primary indication of attaining competitive advantage. The study concluded that in the long run, there will be a positive relationship between R\&D and economic growth rate of South Africa.

Due to the limitations of data accessibility, annual data for ECOWAS member states for the period of 2001-2014 was used to conduct an analysis of the macroeconomies of the member states. A gap in the literature for ECOWAS member states was filled by estimating an empirical model which is consistent with an 
augmented Solow growth model that includes in its specification the ratio of R\&D to GDP and also human capital [21].

The main objective of our study was to find out whether R\&D influenced economic growth in ECOWAS member states. An auxiliary objective was to find out whether stock of knowledge had an influence on R\&D. Since the analysis dealt with various countries, attempts were made in order to ensure cointegration existed in the long run relationship of the variables. A unit root analysis was conducted to check the presence of panel unit root in the variables. Based on the outcome of the unit root analysis the cointegration test was be conducted if there existed unit root in the variables to evaluate the long-term relationship between the variables. Then the Generalized Least Squares (GLS) method with dynamic panel data estimators was used to find the relationship between the variables. The GLS was used because it more robust in curbing certain degree of correlation between the residuals in a regression model. Therefore the GLS is preferred over Ordinary Least Squares (OLS) because it can be statistically inefficient, or even give misleading inferences

\section{Patterns of GDP and R\&D in West African Sub-Region}

It is agreed by African head of states and some scholars that for the development of the African continent, R\&D must be taken seriously. This implies that the development of the African continent requires the metamorphosing from the reliance on natural resources to a value and knowledge-based economy. The over reliance on natural resources does not promote economic growth but rather a stagnant development. The developed nations have moved pass this stage only through innovation and advancement in technology [9]. It is in this regard that the head of states in Africa through various meetings in the African Union Commission (AUC) came to a consensus to allocate about $1 \%$ from their various GDP towards the enhancement of R\&D [22].

In July 1979 and April 1980, the Monrovia Strategy and the Lagos Plan of Action (LPA) respectively were espoused by the heads of states of Africa (1980-2000). Their intentions for assumption of these action plans were to enhance the development of economic growth of African countries. The LPA was the first of its kind to be proposed on how the African continent learnt to independently cooperate on issues that bordered on the growth of the continent. This however, laid the grounds for successive African development agendas.

The LPA inspired the following gatherings and enactments. First, the CASTAFRICAII conference was organised by UNESCO/OAU/ECA, where economic recovery tactics for Africa were looked at. It was well attended by 26 Science, Technology and Innovation (STI) ministers from African countries and experts. In addition, the Abuja Treaty was also embraced in 1994. Its aim was to give birth to an African Economic Community (AEC) which ensured a common gain for the continent through economic assimilation. Similarly, in July 2001 the Organisation of African Unity (OAU) was transformed to African Unity (AU) in 
Lusaka, Zambia with the aim to "build an integrated, prosperous and peaceful Africa, an Africa driven and managed by its own citizens and representing a dynamic force in the international arena" [23].

Knowing the prospects emanating from STI, several calls ${ }^{3}$ have been made to increase the $1 \%$ investment of each African country's GDP towards R\&D enhancement. In light of this, a conference of Ministers in charge of Science and Technology (AMCOST) was instituted by the AUC. Its purpose was enable the ministers have a unanimous say on matters bordering on STI. In 2005, the (AMCOST) developed a Consolidated Plan of Action (CPA) for science and technology in Africa. Its focus was for the action plan to serve as a guide in determining the total expenditure towards R\&D in each African country. In September 2007, the CPA gave birth to the African Science, Technology and Innovation Indicators Initiative (ASTII). During the creation of ASTII, the Intergovernmental Committee on ASTII meeting in Maputo resolved that African countries should apply internationally recognised mechanisms and guidelines to assess R\&D and innovation programmes. The Organisation for Economic Development's (OECD) Frascati and the OECD/Eurostat Oslo Manuals were recommended as key points of reference in conducting surveys and developing standard indicators of STI in Africa [24].

\section{Theoretical Framework}

The model adopted for the purpose of this work was the standard growth equation model. It explained a country's aggregate production function as a CobbDouglas type as in [21] [25]. In this model the concept of human capital was introduced which helped to establish a relationship between $R \& D$ expenditure, productivity and possibly other inputs, as in the case of [26]. This idea follows the EGT.

$$
Y=A K^{a_{1}} L^{a_{2}} R D^{a_{3}} H C^{a_{4}}
$$

where $Y$ is the real output, $K$ denotes aggregate capital input, $L$ is the total labour input, $H C$ represents the human capital stock and $\mathrm{R} \& \mathrm{D}$ represents the research and development stock. Also, $A$ denotes a positive constant. To add, $\alpha_{1}, \alpha_{2}, \alpha_{3}$ and $\alpha_{4}$ constitute exponents (positive fractions) of $K, L, R D$ and $H C$ respectively. We start by taking the natural log of both sides of Equation (1) we find that:

$$
\ln Y=A+a_{1} \ln K+a_{2} \ln L+a_{3}+\ln R D+a_{4} H C
$$

The availability of data in the West African sub-region on the independent variables was challenging. Therefore, proxy variables were used in replace of the independent variables.

These proxies are gross fixed capital formation (gfcf), GDP per person em-

${ }^{4}$ Such calls for increased investment in R\&D included the Monrovia Declaration of 1979, the Eighth Ordinary Session of the Executive Council of the AU that met in 2006 in Khartoum, Sudan and the Ninth Executive Council of the AU held in Addis Ababa, Ethiopia in 2007 [24] A. Union, Science, technology and innovation strategy for Africa 2024 (STISA-2024), in, Addis Ababa: African Union Commission, 2014. 
ployed (gdpppe), government expenditure on tertiary education as a \% of GDP (geote) and gross enrolment ratio, both sexes \% (ger) for capital (K), labour (L), $\mathrm{R} \& \mathrm{D}(\mathrm{RD})$ and human capital (HC) respectively.

\section{Methodology and Results}

Table 1 reports summary statistics of our sample. On average, the countries have about $7.4 \%$ of gross expenditure on tertiary education, $13.3 \%$ of gross employment rate per person employed in the various countries, $46.5 \%$ of enrolment rates of both sexes into the tertiary institutions and about $180 \%$ of fixed capital formation yearly which roughly corresponds to about $46 \%$ of gross domestic product per capital growth of the countries. Generally, it could be observed that less attention is placed on the expenditure on tertiary education which is the point at which students should be motivated and encouraged to be creative and innovative.

\section{Estimating the Cobb Douglas Production Function and Results}

From the presentation of the theoretical framework in the preceding section, we can proceed by applying econometric tools to our Cobb-Douglas production function. That is by obtaining the estimates of the parameters $A, a_{1}, a_{2}, a_{3}$ and $a_{4}$. The implication of the production function is that the output level $Y$ depends upon $K, L, R D$ and $H C$. A regression analysis is done on the transformed logarithm of the production function. The regression would provide us with estimates of $a_{1}, a_{2}, a_{3}$ and $a_{4}$. The estimates of $a_{1}, a_{2}, a_{3}$ and $a_{4}$ could be used to determine phenomenon of returns to scale. If sum of these estimates is equal to one, then it implies constant returns to scale; if it is less than one, then it is decreasing returns to scale and if it is greater than one, it is increasing returns to scale. The production function has an implicit assumption that $A$ (level of technology) is fixed over time. This however is not applicable in the real world therefore $A$ needs to be varied. This we do by differentiating the transformed logarithm of the production function.

$$
\begin{gathered}
\ln (Y)=1.49013-0.0039 \ln (\text { gfcf })+0.25095 \ln (\text { gdpppe }) \\
+0.05031 \ln (\text { ger })+0.11327 \ln (\text { goete }) \\
(0.237) * * * \quad(0.075) * * * \quad(0.044) * * *
\end{gathered}
$$

Table 1. Descriptive Statistics.

\begin{tabular}{cccccc}
\hline Variables & Obs & Mean & Std. Dev. & Min & Max \\
\hline goete & 203 & 0.7397634 & 0.4141411 & 0.0002 & 1.92761 \\
Ger & 200 & 4.6505989 & 4.903917 & 0.00211 & 22.98218 \\
Gdpppe & 125 & 1.32958 & 1.777474 & -4.66128 & 7.874914 \\
Gfcf & 132 & 17.9934 & 9.758108 & 2.075241 & 46.44408 \\
Gdpg & 210 & 4.605989 & 4.903917 & -30.14522 & 33.73577 \\
\hline
\end{tabular}


Table 2 and Table 3 indicate that lnppe and lngoete are significant and that their coefficients are positively impacting on GDP. The 0.25095 estimate for $\alpha_{2}$ indicates that a 1 percent increase in the employment level leads to a 0.251 percent increase in the real GDP level. Similarly, the 0.11327 estimate for $\alpha_{4}$ indicates that a 1 percent increase in the $R \& D$ level leads to a 0.113 percent increase in the GDP level.

In the case of Equation (1), it is possible to determine the level of change (either increase or decrease) on GDP to a corresponding change on all the input factors. Therefore from (1) we can get:

Table 2. Description of variables.

\begin{tabular}{|c|c|c|}
\hline Variables & Description & Source \\
\hline $\ln g d p g_{i, t}$ & $\begin{array}{l}\text { Natural logarithm of GDP per } \\
\text { capita growth (annual \%) }\end{array}$ & $\begin{array}{l}\text { Authors' calculation based on World } \\
\text { Bank-world development indicators }\end{array}$ \\
\hline $\ln g f c f_{i, t}$ & $\begin{array}{l}\text { Natural logarithm of Gross fixed } \\
\text { capital formation (\% of GDP) }\end{array}$ & $\begin{array}{l}\text { Authors' calculation based on World } \\
\text { Bank-world development indicators }\end{array}$ \\
\hline$g d p p p e_{i, t}$ & $\begin{array}{l}\text { Natural logarithm of GDP per person } \\
\text { employed (constant } 2011 \text { PPP \$) }\end{array}$ & World Bank-world development indicators \\
\hline $\ln g e r_{i, t}$ & $\begin{array}{l}\text { Natural logarithm of Gross } \\
\text { enrolment ratio, tertiary, both sexes } \\
(\%)\end{array}$ & $\begin{array}{c}\text { Authors' calculation based on } \\
\text { World Bank-education statistics }\end{array}$ \\
\hline $\ln _{\text {goete }}{ }_{i, t}$ & $\begin{array}{c}\text { Natural logarithm of Gross expenditure } \\
\text { on tertiary education (\% of GDP) }\end{array}$ & $\begin{array}{l}\text { Authors' calculation based on World } \\
\text { Bank-world development indicators }\end{array}$ \\
\hline
\end{tabular}

Table 3. The results of the regressive estimation of the variables.

\begin{tabular}{|c|c|c|c|c|}
\hline lngdpg & Coef. & $P>t$ & [95\% Conf. & Interval] \\
\hline $\operatorname{lngfcf}$ & $\begin{array}{l}-0.003894 \\
(0.082904)\end{array}$ & 0.963 & -0.1687577 & 0.1609697 \\
\hline lngdpppe & $\begin{array}{c}0.2509485^{* * *} \\
(0.0750748)\end{array}$ & 0.001 & 0.1016541 & 0.4002429 \\
\hline lnger & $\begin{array}{c}0.05031 \\
(0.0323104)\end{array}$ & 0.123 & -0.0139428 & 0.1145628 \\
\hline lngoete & $\begin{array}{c}0.1132657^{* * *} \\
(0.0436209)\end{array}$ & 0.011 & 0.0265207 & 0.2000106 \\
\hline _cons & $\begin{array}{l}1.490128^{* * *} \\
(0.2386068)\end{array}$ & 0 & 1.015632 & 1.964624 \\
\hline Number of obs $=$ & 89 & & & \\
\hline$F(4,84)$ & 8.06 & & & \\
\hline Prob $>$ F & 0 & & & \\
\hline R-squared & 0.2773 & & & \\
\hline
\end{tabular}

Notes: 1) The figures in the parenthesis are the standard errors. 2) ${ }^{* * *}$ denotes statistical significance at $5 \%$ level. 


$$
C(y, r, w, p, q)=h \cdot y y^{\frac{1}{\phi}} \cdot r^{\frac{a_{1}}{\phi}} \cdot w^{\frac{a_{2}}{\phi}} \cdot p^{\frac{a_{3}}{\phi}} \cdot q^{\frac{a_{4}}{\phi}}
$$

where $\phi=a_{1}+a_{2}+a_{3}+a_{4}$ is the returns to scale parameter and

$$
h=\phi\left[a_{1}^{a_{1}} \cdot a_{2}^{a_{2}} \cdot a_{3}^{a_{3}} \cdot a_{4}^{a_{4}}\right]^{-\frac{1}{\phi}}
$$

Taking the $\log$ of this equation and adding an error term $\left(\varepsilon_{i}\right)$ yields the equation estimated by [27]

$$
\begin{aligned}
\ln C_{i}= & \beta_{0}+\beta_{y} \cdot \ln \left(y_{i}\right)+\beta_{K} \cdot \ln \left(K_{i}\right)+\beta_{L} \cdot \ln \left(L_{i}\right) \\
& +\beta_{R D} \cdot \ln \left(R D_{i}\right)+\beta_{H C} \cdot \ln \left(H C_{I}\right)+\varepsilon_{i}
\end{aligned}
$$

In this model we know that if returns to scale are going to depend on the value of $\varphi=a_{1}+a_{2}+a_{3}+a_{4}$.

Then:

If $\varphi=1$, the production function has constant returns to scale.

If $\varphi>1$, the production function has increasing returns to scale.

If $\varphi<1$, the production function has decreasing returns to scale.

To find out the level of GDP that is being influenced with a corresponding input factor, it can be seen from Table 1 that estimates for $a_{2}$ implies there is a decreasing return to labour with respect to GDP. That is the 0.25095 estimate for $\beta$ indicates that a 1 percent increase in employment leads to a 0.251 percent increase in the GDP level. Similarly, the estimates for $a_{4}$ imply there is decreasing returns to $\mathrm{R} \& \mathrm{D}$ with respect to GDP. That is the 0.11327 estimate for $\gamma$ indicates that a 1 percent increase in $R \& D$ leads to a 0.113 percent increase in the GDP level.

Similarly, the sum of $a_{1}+a_{2}+a_{3}+a_{4}=0.41063$. The outcome of 0.41063 is however less than one, which denotes that GDP shows characteristics of "decreasing returns to scale." A decreasing return to scale implies that a percentage increase in all inputs leads to a less than percentage decrease in the GDP. Therefore, doubling the inputs would mean that the outcome of the GDP will also be doubled but still not more than one. That is, $a_{1}+a_{2}+a_{3}+a_{4}=41.063$ which shows that GDP had doubled as a result of a hundred percent increase in the inputs. The results still indicate decreasing returns to scale since the outcome of GDP is less than the amount of increase in inputs.

From the production function in Equation (1) it is observed that there is an implicit assumption that $A$ is fixed over time (or has a positive constant) which is assumed to be the level of technology. On the contrary, technology is expected to be dynamic and therefore does not reflect happenings in the real world. For technology to be assumed to be dynamic, Equation (2) will be differentiated with respect to time and while assuming time is dependent. Doing so, we obtain

$$
\frac{1}{Y} \frac{\mathrm{d} Y}{\mathrm{~d} t}=\frac{1}{A} \frac{\mathrm{d} A}{\mathrm{~d} t}+\alpha \frac{1}{K} \frac{\mathrm{d} K}{\mathrm{~d} t}+\beta \frac{1}{L} \frac{\mathrm{d} L}{\mathrm{~d} t}+\gamma \frac{1}{R D} \frac{\mathrm{d} R D}{\mathrm{~d} t}+\rho \frac{1}{H C} \frac{\mathrm{d} H C}{\mathrm{~d} t}
$$

where $\frac{1}{Y} \frac{\mathrm{d} Y}{\mathrm{~d} t}$ denotes the growth rate of $Y$, we can define a new variable $g_{Y}$ 
for the growth rate of $Y$. Similarly, we can define the variables $g_{A}, g_{K}, g_{L}$, $g_{R D}$ and $g_{H C}$ for the growth rates of technology, capital, labour, R\&D and human capital and we can rewrite (5) as

$$
g_{y}=g_{A}+\alpha g_{K}+\beta g_{L}+\gamma g_{R D}+\rho g_{H C}
$$

Just as in the case of Equations (1) where the level of technology was assumed constant, so will the growth rate of technology be in model (5) while the level of technology changes. The growth rate of GDP on that of the growth rates of the input factors. Doing so, we obtain Table 4 below.

$g_{Y}=-0.0150057-0.2249671 g_{K}+0.0157849 g_{L}+0.1267035 g_{H C}+0.1453109 g_{R D}$ $(0.1267035) * * * \quad(0.0392197) * * *$

Equation (7) shows that the average growth rate for technology (average of the variable $\left.g_{A}\right)$ is $-0.0150057=-0.015 \%$ per year. The coefficients of $a_{3}=$ 0.1267035 and $a_{4}=0.1453109$ are the assumed elasticities for HC and R\&D respectively. These coefficients imply that a 1 percent increase in HC and R\&D will lead to a 0.127 and 0.145 percent increase in GDP respectively. This outcome also indicates a decreasing return to scale. Summing the coefficients of $a_{1}+a_{2}+a_{3}+a_{4}=0.0628322$. Comparing the outcomes of GDP when technology was constant and when it was varied, the initial outcome had a higher GDP than the former. This however suggests that the West African sub-region is reluctant to embrace technological change and therefore will prefer to invest in other sectors.

Table 4. The results of the regressive estimation of the variables.

\begin{tabular}{ccccc}
\hline lngdpg & Coef. & $\mathrm{P}>\mathrm{t}$ & $95 \%$ Conf. & Interval \\
\hline lngdfcfD1 & -0.2249671 & 0.323 & -0.6767771 & 0.226843 \\
& $(0.2257112)$ & & & \\
lngdpppeD1 & 0.0157849 & 0.904 & -0.2438433 & 0.275413 \\
& $(0.1297027)$ & & & \\
lngerD1 & $0.1267035^{* * *}$ & 0.007 & 0.0356188 & 0.2177882 \\
& $(0.0455033)$ & & & 0.2238176 \\
lngoeteD1 & $0.1453109^{* * *}$ & 0.000 & 0.0668042 & \\
& $(0.0392197)$ & & & \\
_cons & -0.0150057 & 0.84 & -0.1631513 & \\
& $(0.0740092)$ & & & \\
Number of obs $=$ & 63 & & & \\
F( 4, 58) & 7.26 & & & \\
Prob> F & 0.0001 & & & \\
R-squared & 0.3337 & & & \\
\hline
\end{tabular}

Notes:1) The figures in the parenthesis are the standard errors. 2) ${ }^{\star * \star}$ denotes statistical significance at $5 \%$ level. 


\section{Conclusions}

The purpose of this paper was to study the influence of $R \& D$ (which included capital, labour and human capital) on economic development in the West African sub-region. However, due to unavailability of data to cover these variables, proxies were used to represent the independent variables. These proxies are gross fixed capital formation, gross domestic product per person employed, government expenditure on tertiary education and gross enrolment ratio (both sexes) to represent capital, labour, R\&D and human capital respectively. The West African sub-region is made of 15 countries $^{3}$. The study covered a period of 2001-2014 while the GLS method of estimation was adopted with a panel dataset. The findings first of all revealed that the independent variables (i.e. gross domestic product per person employed and government expenditure on tertiary education) had a significant influence on the independent variable (per capita) with the level of technology being constant. The level of significance was however weakly positive. The results also indicated that there was decreasing returns to scales on the GDP. That is, a proportionate increase in all inputs leads to less than proportionate decrease in the GDP. This therefore, meant that the amount of resources invested in the input did not yield an equal or more GDP but rather less. However, operating in a real world would mean that technology could not be constant. Therefore, it was varied in order to observe the growth rates of the inputs and GDP. The findings revealed that both $\mathrm{R} \& \mathrm{D}$ and $\mathrm{HC}$ had a positive influence on GDP (per capita). It was again noticed that they both had a decreasing returns to scale on GDP.

It can however be said that the member states of ECOWAS continuous investment in the R\&D and the development of the HC sectors especially in education would encourage innovation, novelty and creativity resulting in competition and efficiency thereby leading to higher production. The findings are in line with the endogenous growth literature of Romer [11], Ghura, Basu and Calamitsis [1], Sylwester [7], and Ulku [12] where emphases were made for governments to be actively involved in the development of a vibrant R\&D sector by investing in the development of human capital (education).

Most governments over the past years particularly in the developed economies have acknowledged the significance of R\&D to economic growth. They therefore have invested more large amounts of money on regular basis to the development of research institutions. However, based on this revelation about the importance of R\&D coupled with a strong human resource base on economic development as could be seen in the outcome of the results, it is recommended that West African governments should adopt policies that are appropriate and create conducive operation conditions which promotes science, technology and innovation within each country and possibly within the sub-region. These policies should be geared towards encouraging interest in science and technology research in ${ }^{4}$ Benin, Burkina Faso, Cape Verde, Cote d'Ivoire, The Gambia, Ghana, Guinea, Guinea-Bissau, Liberia, Mali, Niger, Nigeria, Senegal, Sierra Leon and Togo. 
higher institutions of study and research bodies (laboratories) on one hand and the manufacturing sector on the other hand. It is also recommended that head of states of the West African sub-region should endeavour to be committed to meeting the $1 \%$ investment of their various GDP towards the enhancement of $\mathrm{R} \& \mathrm{D}$ as agreed by the African Union Commission (AUC), since most developed nations have moved pass this stage only through innovation and advancement in technology [9]. In future, we hope to further discuss the involvement of the private sector in the usage of science, technology and innovation towards economic development and whether higher investment in research institutions could lead to the growth of $\mathrm{R} \& \mathrm{D}$ in the business sector.

By these results, we conclude that government's expenditure in education is the best proxy for $\mathrm{R} \& \mathrm{D}$ as compared to other variables used in the study.

\section{Acknowledgements}

This work was sponsored by the Qing Lan Project of Jiangsu Province and the Key Members of Outstanding Young Teacher Training Project of Jiangsu University.

\section{References}

[1] Ghura, M.D., Basu, M.A. and Calamitsis, M.E.A. (1999) Adjustment and Growth in Sub-Saharan Africa. International Monetary Fund.

[2] Acemoglu, D. and Robinson, J.A. (2010) Why Is Africa Poor? Economic History of Developing rEgions, 25, 21-50. https://doi.org/10.1080/20780389.2010.505010

[3] Ulku, H. (2004) R\&D, Innovation, and Economic Growth: An Empirical Analysis. International Monetary Fund. https://www.imf.org/external/pubs/ft/wp/2004/wp04185.pdf

[4] Nkurunziza, J.D. and Bates, R.H. (2003) Political Institutions and Economic Growth in Africa. University of Oxford, Centre for the Study of African Economies.

[5] Marc, A., Verjee, N. and Mogaka, S. (2015) The Challenge of Stability and Security in West Africa. World Bank Publications. https://doi.org/10.1596/978-1-4648-0464-9

[6] Taje, M. (2010) West African Challenges, Vulnerabilities and Factors of Insecurity in the Sahel.

[7] Sylwester, K. (2001) R\&D and Economic Growth. Knowledge, Technology \& Policy, 13, 71-84. https://doi.org/10.1007/BF02693991

[8] Rita, F. and Signe, B. (2016) Research and Development Expenditures and Economic Growth in the EU: A Panel Data Analysis. Economics and Business, 29, 5-11.

[9] Gault, F. (2008) Science, Technology and Innovation Indicators: Opportunities for Africa. African Statistical Journal, 6, 141-161.

[10] Pessoa, A. (2010) R\&D and Economic Growth: How Strong Is the Link? Economics Letters, 107, 152-154. https://doi.org/10.1016/j.econlet.2010.01.010

[11] Romer, P.M. (1990) Endogenous Technological Change. Journal of political Economy, 98, S71-S102. https://doi.org/10.1086/261725

[12] Ulku, H. (2007) R\&D, Innovation and Output: Evidence from OECD and Non OECD Countries. Applied Economics, 39, 291-307. 
https://doi.org/10.1080/00036840500439002

[13] Pissarides, C.A. (2000) Human Capital and Growth. Volume 168 of Technical Papers//OECD Development Centre Issue 168 of OECD Development Centre Technical Papers.

[14] Lehtoranta, O. (2005) Determinants of Innovation and the Economic Growth of Innovators. Tracing the Evolution of Innovative Firms over Time. In VTT Working Papers.

[15] Nicolaides, A. (2014) Research and Innovation-The Drivers of Economic Development. African Journal of Hospitality, Tourism and Leisure.

[16] Salter, A.J. and Martin, B.R. (2001) The Economic Benefits of Publicly Funded Basic Research: A Critical Review. Research Policy, 30, 509-532. https://doi.org/10.1016/S0048-7333(00)00091-3

[17] Gumus, E. and Celikay, F. (2015) R\&D Expenditure and Economic Growth: New Empirical Evidence. Margin: The Journal of Applied Economic Research, 9, 205-217. https://doi.org/10.1177/0973801015579753

[18] Dulleck, U. and Foster, N. (2008) Imported Equipment, Human Capital and Economic Growth in Developing Countries. Economic Analysis and Policy, 38, 233-250. https://doi.org/10.1016/S0313-5926(08)50019-1

[19] Alani, J. (2012) Effects of Technological Progress and Productivity on Economic Growth in Uganda. Procedia Economics and Finance, 1, 14-23. https://doi.org/10.1016/S2212-5671(12)00004-4

[20] Anaduaka, U.S. (2014) Human Capital Development and Economic Growth: The Nigeria Experience. International Journal of Academic Research in Business and Social Sciences, 4, 25.

[21] Silaghi, M.I.P., Alexa, D., Jude, C. and Litan, C. (2014) Do Business and Public Sector Research and Development Expenditures Contribute to Economic Growth in Central and Eastern European Countries? A Dynamic Panel Estimation. Economic Modelling, 36, 108-119. https://doi.org/10.1016/j.econmod.2013.08.035

[22] Iizuka, M., Mawoko, P. and Gault, F. (2015) Innovation for Development in Southern \& Eastern Africa: Challenges for Promoting ST\&I Policy. UNU-MERIT Policy Brief, 1, 1-8.

[23] Union, A. (2015) Agenda 2063: The Africa We Want. African Union Commission, Addis Ababa.

[24] Union, A. (2014) Science, Technology and Innovation Strategy for Africa 2024 (STISA-2024). African Union Commission, Addis Ababa.

[25] Snowdon, B. and Vane, H.R. (2005) Modern Macroeconomics: Its Origins, Development and Current State. Edward Elgar Publishing, Cheltenham.

[26] Mankiw, N.G., Romer, D. and Weil, D.N. (1992) A Contribution to the Empirics of Economic Growth. The Quarterly Journal of Economics, 107, 407-437. https://doi.org/10.2307/2118477

[27] Nerlove, M. (1961) Returns to Scale in Electricity Supply. Institute for Mathematical Studies in the Social Sciences, Stanford University, Stanford, CA. 